\title{
Project-Based Learning Model Practicality on Local Network Devices Installation Subject
}

$\underline{\text { https://doi.org/10.3991/ijet.v14i15.10305 }}$

\author{
Ilham Tri Maulana ${ }^{(凶)}$, Restyaliza Dhini Hary, Ratih Purwasih, \\ Fadil Firdian, Tri. A. Sundara \\ STMIK Indonesia, Padang, Indonesia \\ ilhamtmestmikindonesia.ac.id \\ Jufriadif $\mathrm{Na}^{\prime}$ am \\ Universitas Putra Indonesia YPTK, Padang, Indonesia
}

\begin{abstract}
The learning process in vocational high schools is the decisive factor for being able to give birth to vocational secondary education graduates that are in accordance with their competencies. The learning process will determine whether the learning goals will be achieved. This study aims to develop a project-based learning device on the subject of Local Network Devices Installation. The method used is the Instructional Development Institute (IDI) with processed data sourced from 2 teachers and 29 students. The result of this study is practical that a value of $85.75 \%$. It is concluded that this model is very helpful in learning Local Network Device Installation and as a reference model for other subjects.
\end{abstract}

Keywords-Active Learning, Project Based Learning, Learning Outcomes, Instructional Development Institute, Local Area Network Subject

\section{Introduction}

\subsection{Active learning}

The application of active learning requires the ability of teachers to design and develop learning tools in the form of learning models that can help students and teachers in the learning process. Teachers can create active learning environments that involve students to collaborate with each other, especially in developing and designing quality products [1] [1]. Collaboration is a key practice for success in the twenty-first-century economy. To be successful, collaborators are expected to negotiate goals and task standards, to act strategically while monitoring, to revise processes and results, to use appropriate technological tools, and to productively face the challenges they face. Technological approach can also be used as a means of supporting the learning so that the learning process may facilitate the activities of the learning process of learners effectively and efficiently [2]. Technology also allows digital generations of students to be constantly connected with their fellow students, but also with teachers, and to 
get immediate feedback [3]. Research has shown that many students have difficulty developing the competencies needed through classroom learning [4].

The recent study underlines that individual student differences must be considered in the educational environment. For this purpose, it is suggested that the educational environment must be enriched through educational methods that enhance students' ability to connect what they have learned with real life, problem-solving skills and their critical thinking. Project-based learning is one method that directs students to research and produce and ensure they build their own learning process. Through project-based learning (PBL), there will be contributions to raising individuals who are aware of their own learning and skills, knowledge structures, and actively participate in the learning process [5]. Cooperative learning also play as an important component of active learning [6].

\subsection{Project based learning}

One learning model that can accommodate students to be able to conduct research through a simple project is a model of project-based learning. In addition to providing direct experience to students in conducting research, the model project-based learning can also facilitate students to use Installation project proposals for Local Network Devices as learning resources that can support the implementation of research [7].

Project-based learning has advantages among learning models which involve students, improve cooperative learning skills, improve academic performance, develop high-level thinking skills and build positive relationships between students and teachers [8].

Project-based learning is perceived as a learning method, as a philosophy or concept didactic and as a coherence of knowledge construction and research approaches. The research review revealed that the increasing application of-based learning project in educational practices also resulted in changes in the scope of research in fields and methodologies [9]. Project-based learning is a learning method that provides opportunities for students to learn, research and practice on their own, and according to their abilities, talents, and interests using scientific processes, or other possible processes, which can be used to find answers to questions, while the teachers closely provide guidance and advice .

Project-based learning is one of the active learning methods in which several problems and incidents encountered in real life are investigated and the results expressed in oral presentations or written reports. Project-based learning aims for students to acquire scientific skills and furthermore, improve their academic performance [16]. To increase the potential of PBL, projects must be designed to increase student motivation and met cognitive thinking skills. Teachers must also be supported in creating PBL [20].

PBL organizes learning around the project and engages students in authentic situations where they can explore and apply subject matter to complex problems that are relevant to the professional practice they are preparing. The characteristics of PBL are developing students' thinking skills, enabling them to have creativity, encouraging them to work together, and directing them to access their own information and to 
show this information. PBL usually asks students to participate voluntarily in proposed meaningful learning activities, most of the teamwork [10].

In the PBL environment, students learn primarily by building knowledge and making meaning through repetitive questions, active learning, sharing, and reflection. This learning service emphasizes educational opportunities that are interdisciplinary, student-centered, collaborative, and integrated with real-world problems and practices. It has been reported that this approach is effective and is widely used in various classroom settings. Project-based learning gives students the possibilities and motives for working with their solutions in their own special way [11].

Many studies in this decade have shown that project-based learning is an effective teaching strategy to improve student learning motivation and help students engage in learning activities. Some researchers suggest that self-learning of elementary school students can be stimulated in PBL activities. Some research results show that PBL has the potential to improve student learning outcomes. In summary, evidence of the potential of the PBL approach, especially facilitating learning achievement and student motivation is well documented in previous studies [10].

Previous research stated one of the learning strategies for developing writing skills was project-based learning. This strategy forces students to do reflective thinking that is useful for improving student competence. In addition, this strategy emphasizes writing articles that are practically under the supervision of lectures. So, each student can make academic articles at the end of the learning program [12].

\section{I.3 IDI model}

The Instructional Development Institute (IDI) is a learning model developed by the University Consortium for Instructional Development and Technology (UCIDT), which consists of the University of South California (USC), International University in San Diego, Michigan State University (MSU), Syracuse Uni-versity and Indiana University, this learning model was developed and tested in several countries in Asia and Europe and has been successful in 334 educational institutions in America [13].

The IDI model is a complex and integrated learning model of people, procedures, ideas, tools and organizations to manage problem solving efforts in learning and controlled situations. Problem solving is in the form of a complete instructional system, which is a combination of in-truck system components that are intentionally designed to be chosen and used in an integrated manner. The IDI model serves to help schools with limited resources. There are a number of teachers who have strong dedication and want to help students, and expect to find innovation as an effective solution for solving learning and learning problems. Quality learning can be seen from optimal learning outcomes, so that to obtain optimal learning outcomes closely related to learning processes carried out based on the competencies of learning activities that are carried out consciously with full responsibility to provide knowledge, attitudes, and skills to students.

The IDI (Instructional Development Institute) learning model offers programmatic development in designing learning, so that students learn actively, which emphasizes the provision of learning resources. The development model of IDI applies the princi- 
ples of a system approach which includes three stages, namely discovery (define) or needs analysis, development (develop), and evaluation (evaluate) [14].

\subsection{Vocational secondary education}

The definition of Vocational Secondary Education is listed in Government Regulation No. 74/2008 is a formal education unit that organizes vocational education at the secondary education level as a continuation of several types of junior secondary education [15]. Vocational secondary education is a form of education organized by the government to produce quality human beings, whose graduates are expected to enter employment and develop attitudes in professional accordance with their respective fields. The learning process in vocational high schools is the decisive factor for being able to give birth to vocational secondary education graduates that are in accordance with their competencies because this learning process will determine whether the learning goals will be achieved or not.

Achievement of learning objectives is characterized by changes in behavior. This change in behavior includes knowledge (cognitive), skills (psychomotor) and attitudes (effective). The main factors that influence learning outcomes are internal and external. Internal factors include body, intelligence, motivation, attention, interest, talent and readiness. While external factors, they consist of family, community, curriculum and learning model. Learning systems are able to provide meaningful learning experiences to students to open up their unique potential in internalizing knowledge, skills, and attitudes [16].

One of the government's efforts to achieve the success of national education is by compiling a curriculum[17]. Vocational Middle School curriculum in various parts of the world is offered to prepare students to work or continue their education to university [18]. Improving the quality of vocational secondary education is carried out gradually and continuously in various components of education, one of the components of education that is used as a reference by each education unit is the curriculum. Vocational secondary education graduates need a variety of skills that continue to increase to maintain relevance to the global environment of the new millennium [19].

Learning systems with the tools of methods and strategies in them are an important part of producing graduates who are highly competitive [16]. Along with the changes in the education curriculum from the Education Unit Level Curriculum (KTSP) to Curriculum 2013 and some schools were returned to the KTSP curriculum which essentially was designed in the form of active learning and student-centered, so students are expected to construct their own knowledge/understanding. Student-centered learning is one of several learning management systems that encourage students to learn and solve problems independently [20].

In addition, in the learning activities, the teacher must be able to integrate the subject matter with the students' real-world situations so that the knowledge gained can be more meaningful and lasting. Therefore, the teacher can determine the learning model and strategy that can lead students to learn more meaningfully and pleasantly. In its application, the teacher is given the freedom to plan, implement and assess the curriculum and student learning outcomes when delivering core competencies and 
basic competencies as a reflection of mastery and understanding of the subjects of the training being studied in Vocational High School (SMK) [14].

Vocational High School is an upper secondary vocational education unit provided by the government in order to prepare ready-to-use workers. This is in accordance with the instructional objectives of vocational secondary education, namely students are expected to become professionals who have adequate, productive, creative skills and are capable of entrepreneurship. The creation of vocational graduates who have quality and ready to use in their fields, it needs efforts to achieve these qualities such as completing facilities and infrastructure, improving the quality of teaching staff, and improving curriculum that emphasizes the development of aspects that lead to improvement and development of life skills which is realized through the achievement of competencies of students to be able to adapt, and succeed in the future.

\subsection{LAN subject}

One of the subjects that must be followed by class XI students in the Department of Information and Communication Technology (TKI) is the Local Network Device Installation which is the subject of the $\mathrm{C} 2$ (Productive) group. In the Lesson Plan (RPP) for Local Network Device Installation subjects, Basic Competencies that must be mastered by students are as follows as shown in Table 1 .

Table 1. Basic Eye Training Local Network Installation

\begin{tabular}{|c|c|l|}
\hline No & Competencies & \multicolumn{1}{|c|}{ Description } \\
\hline 1 & Basic Competence & Create Initial Design of local Networks \\
\hline 2 & Indicators & $\begin{array}{l}\text { Definition of LAN, WAN, MAN, Internet, Bandwidth } \\
\text { Types of topologies and computer network architecture } \\
\text { Protocols on networks computer } \\
\text { Basic principles of addressing IP Address } \\
\text { Definition and ways of working DNS and DHCP }\end{array}$ \\
\hline 3 & Learning Materials & $\begin{array}{l}\text { Explain the types and functions of LAN devices and their expansion } \\
\text { Explaining Types of Media Transmission of Networks Computer } \\
\text { Explaining the basic concepts of cabling UTP based on the types of } \\
\text { connections that exist on the LAN } \\
\text { Performing Installation of UTP Cables based on colour specifications } \\
\text { according to the type of LAN connection The }\end{array}$ \\
\hline
\end{tabular}

Data in Table 1 are the results of discussions from teachers in Local network Device Installation Subjects. This data is used to create textbooks and student books in project-based learning. Based on observations that have been made in the Department of Computer Engineering (TKJ) at Muhammadiyah 1 Padang Vocational School, the tendency of the learning process during this time the local network device installation teacher uses the direct learning model (lecture) while this subject is one of the productive subjects, therefore the teacher must be able to apply a suitable learning model. Many teachers agree that the learning model is directly disrupted by ineffective learning patterns and therefore strongly requires the modernization of the learning model [21]. Innovation in learning models is needed in installation learning Network devices are needed to maximize every effort in increasing the level of student learning skills 
[22]. In addition, it is also important to apply a complex approach in the development of creativity, where educational, sociocultural, and individual factors are considered[23]

Problem-solving requires all teachers to understand several components. One of them is understanding the knowledge content of the domain (knowledge of facts, ideas, principles) [24]. In everyday teaching practice, trust plays an important role in shaping teacher instruction. A large amount of evidence from various countries shows that teacher beliefs significantly influence how they plan, organize, and implement their learning and how responsive they are to their students [25].

In addition, most students study in a learning environment full of teacher-centred teaching. Students are accustomed to receiving step-by-step instructions. Learning knowledge from textbooks and examinations is not normally transferred to everyday life and to the work they take. Teaching in vocational schools emphasizes practical knowledge and direct ability; some of them have problem-solving experience, so teachers in vocational high schools have difficulty teaching students to solve problems [10]. One of the successes in learning is determined by the success of educators in choosing learning strategies [26].

\section{Research Methods}

\subsection{Method}

Based on the problems in this study, the type of research that was conducted is development research. The development model used was the model Instructional Development Institute (IDI). IDI applies the principles of a systematic approach which includes three stages, namely discovery (define) or needs analysis, develop (develop), and evaluation (evaluate) [5].

The first stage is the stage of define which contains steps to identify problems, analyze curriculum, analyze student characteristics, analyze concepts/learning materials and analyze learning models. The second stage, the stage of develops (development) which contains the preparation of the initial form (prototype) products and validation of the learning model. The third stage is the stage of evaluating (evaluation) which contains the steps of the trial and analysis of the results of the trial through questionnaire analysis /questionnaire on a Likert scale distributed to students [1].

The researcher chose the IDI model because the researchers saw that the model with this system approach was in accordance with the problems behind this research. With the needs analysis, looking at the characteristics of students, and with the conditions of the existing school facilities, the researchers hope that with this model a practical learning model can be developed to improve the learning outcomes of Local Network Device Installation subjects. 


\subsection{Tools and technique}

The type of data used in the development of project-based learning is primary data, meaning that the data is directly obtained from the subject of research that is already validated by experts/experts and practical.

The place of research is students who will be given learning using project-based learning. The subjects for the trial of the development of this project-based learning device were the eleventh-grade students of the TKJ department of the Vocational School Muhammadiyah 1 Padang On the even semester 2017/2018 local network equipment installation subjects.

\subsection{Measurement}

Practical test data for project-based learning devices was obtained from teacher and student practice data. Practical data by teachers and students are analyzed using the following steps:

- Give the correct answer based on these criteria: t:

$5=$ very practical, $4=$ praktis, $3=$ Quite Practical, $2=$ Less Practical, $1=$ Unpractical.

- Sum score of each validator.

- Find Practicality Score according to this formula:

$$
\text { Practicality Score }=\frac{\sum \text { score of each item }}{\sum \text { Maximum Score }} \times 100 \%
$$

- To determine practicality category, we may refer to Table 2 .

Table 2. Practicality Category [27]

\begin{tabular}{|c|c|l|}
\hline No & Assesment Score (\%) & \multicolumn{1}{|c|}{ Category } \\
\hline 1 & $90-100$ & Very practical \\
\hline 2 & $80-89$ & Practical \\
\hline 3 & $65-79$ & Quite Practical \\
\hline 4 & $55-64$ & Less Practical \\
\hline 5 & $0-54$ & Unpractical \\
\hline
\end{tabular}

\section{Results and Discussion}

Based on the suggestions given by the validator, a revision was made so that a practical and feasible project-based learning device was obtained to be tested as a learning device in the Local Network Device Installation subject. Practical test data for project-based learning devices in Local Network Device Installation subjects were taken from questionnaires that had been distributed to teachers and students. 


\subsection{Practicality test data based on practitioner / teacher response}

Practicality Related to the ease of use of the learning model developed. Practical data obtained through questionnaires filled with 2 (two) teachers from questionnaire contents can be seen in the practicality of the media. The results of an assessment of the practicality of learning tools are summarized in Table 3.

Table 3. Data from the practicalities of a learning device according to the response of teachers

\begin{tabular}{|c|c|c|c|c|c|}
\hline \multirow{2}{*}{ No } & \multirow{2}{*}{ Scoring Aspect } & \multicolumn{3}{|c|}{ Ratings Percentage (\%) } & \multirow{2}{*}{ Category } \\
\hline & & $T 1$ & $T 2$ & Average & \\
\hline 1 & Ease of Use & 80 & 80 & 80 & Practical \\
\hline 2 & Organizations & 80 & 70 & 75 & Quite Practical \\
\hline 3 & Interpreation of Learning Device & 93 & 93 & 93 & Very Practical \\
\hline 4 & Equivalence & 100 & 90 & 95 & Very Practical \\
\hline & Average & 88 & 83 & 85.75 & Practical \\
\hline
\end{tabular}

Where:

$\mathrm{T} 1=$ Teacher 1

$\mathrm{T} 2=$ Teacher 2

From Table 3 above based on data through a questionnaire filled out of 2 teachers towards the practicality of the project-based learning model, the installation subjects of local network devices at Padang 1 Muhammadiyah Vocational High School can be analyzed that in general the two respondents are almost the same value. First, the ease of use of project-based learning tools made by each teacher the average value is $80 \%$ (Practical Practical). In this aspect, learning devices that are made easy to use by the teacher because the learning device is designed systematically and easily understood by teachers and students. Second, from the organizing aspect the project-based learning device gets a different value of teacher 1 , the average value is $80 \%$, while the teacher 2 scores are $70 \%$ so the total score of 2 teachers is $75 \%$ (Quite Practical). In the aspect of organizing project-based learning devices contain procedures and organizing learning to achieve one or several basic competencies made referring to all teacher learning devices including syllabus and lesson learning plans.

Third, in terms of interpreting project-based learning devices get high scores from teachers by giving the same value of $93 \%$ (Very Practical). In the aspect of interpreting the teacher easily interprets each stage in the project-based learning tool. So that teachers can easily teach material to students. Fourth, in terms of equivalence of project-based learning devices get high scores with teachers 1 average value is $100 \%$ and teacher 2 averages $90 \%$ with a final score of $95 \%$. In the aspect of equivalence learning devices are made comparable to students' abilities. From the total average value of the four aspects of the assessment of the practicality of project-based learning devices on the installation subjects of local network devices of class XI students of Muhammadiyah 1 Padang Vocational School according to the response of 2 teachers is 85.75 (Practical). This project-based learning tool is recommended for use in other subjects. 


\subsection{Practicality test data based on student response}

For practicality, the learning model also requires input in the form of responses from 29 students. This data is obtained after learning, through questionnaires given to students. The results obtained as shown in Table 4.

Table 4. Data on Practicality Results of Student-based learning devices

\begin{tabular}{|c|c|c|c|c|}
\hline No & $\begin{array}{l}\text { Practicality } \\
\text { Aspects }\end{array}$ & Assessed Aspects & \begin{tabular}{|c|} 
Assessment \\
Percentage (\%)
\end{tabular} & Remarks \\
\hline \multirow{6}{*}{1} & \multirow{6}{*}{$\begin{array}{l}\text { Ease of users } \\
\text { of learning } \\
\text { devices }\end{array}$} & I can learn project-based lessons easily & \begin{tabular}{ll|}
71 \\
\end{tabular} & Quite Practical \\
\hline & & $\begin{array}{l}\text { With my project-based lessons can learn on } \\
\text { their own even without a teacher }\end{array}$ & 59 & Less Practical \\
\hline & & $\begin{array}{l}\text { With project-based learning becoming more } \\
\text { practical }\end{array}$ & 72 & Quite Practical \\
\hline & & $\begin{array}{l}\text { I can understand learning material easily } \\
\text { through project-based learning }\end{array}$ & 69 & Quite Practical \\
\hline & & $\begin{array}{l}\text { I can repeat the answer to project-based learning } \\
\text { questions at home }\end{array}$ & 66 & Quite Practical \\
\hline & & $\begin{array}{l}\text { project-based learning really helped me in } \\
\text { understand the concepts of learning material }\end{array}$ & 68 & Quite Practical \\
\hline \multirow{3}{*}{2} & \multirow{3}{*}{$\begin{array}{l}\text { Ease of under- } \\
\text { standing } \\
\text { material }\end{array}$} & $\begin{array}{l}\text { With project-based learning, I can understand } \\
\text { the concepts of learning material in a short time }\end{array}$ & 66 & Quite Practical \\
\hline & & $\begin{array}{l}\text { I understand subject matter more quickly if } \\
\text { using project-based lessons }\end{array}$ & 71 & Quite Practical \\
\hline & & Time used project-based learning is very precise & 69 & Quite Practical \\
\hline \multirow{3}{*}{3} & \multirow{3}{*}{$\begin{array}{l}\text { The appeal of } \\
\text { the learning } \\
\text { device }\end{array}$} & I please learning with project-based learning & 76 & Quite Practical \\
\hline & & $\begin{array}{l}\text { Learning with project-based learning intrigued } \\
\text { me to study harder }\end{array}$ & 70 & Quite Practical \\
\hline & & $\begin{array}{l}\text { I do not feel tired of answering the project-based } \\
\text { learning even though for a long time }\end{array}$ & 68 & Quite Practical \\
\hline \multirow{3}{*}{4} & \multirow{3}{*}{$\begin{array}{l}\text { Can be used as } \\
\text { independent } \\
\text { learning }\end{array}$} & I like learning with project-based learning & 74 & Quite Practical \\
\hline & & Project-based learning makes me more creative & 77 & Quite Practical \\
\hline & & $\begin{array}{l}\text { Learning with project-based learning arouses } \\
\text { my interest in self-study }\end{array}$ & 72 & Quite Practical \\
\hline
\end{tabular}

Data above is recapitulated and simplified accordingly with practicality lattice as shown in Table 5.

Table 5. Recapitulation Practicality based on student response

\begin{tabular}{|l|l|c|l|}
\hline No & \multicolumn{1}{|c|}{ Assessment Aspect } & Assessment Percentage (\%) & \multicolumn{1}{c|}{ Category } \\
\hline 1 & Device users lesson & 67 & Quite Practical \\
\hline 2 & Ease of understanding material & 69 & Quite Practical \\
\hline 3 & $\begin{array}{l}\text { The attractiveness of learning devices } \\
\text { learning tools }\end{array}$ & 71 & Quite Practical \\
\hline 4 & Can be used as self-learning & 74 & Quite Practical \\
\hline \multicolumn{2}{|c|}{ Average } & $\mathbf{7 0}$ & Quite Practical \\
\hline
\end{tabular}

From Table 5 above based on data through a questionnaire which was filled out of 29 students towards the practicality of the project-based learning model of local net- 
work device installation subjects at Padang 1 Muhammadiyah Vocational School, we can analyze that: First, the ease of use of project-based learning devices has an average score of $67 \%$ (Quite Practical). In this aspect students can learn practical lessons, be able to understand the material, independently, repeat understanding the material at home again, and help students understand the concept of subject matter. In this aspect, it needs to be considered especially in students who can study on their own even without the teacher. The second point is, in terms of the ease of understanding the material for project-based learning devices the average score is 69\% Quite Practical). In this aspect students can understand the concept of lesson learning in a short time, and the time used for project-based learning is more effective and efficient

Third, in terms of the attractiveness of project-based learning devices, the average value is $71 \%$ (Quite Practical). In this aspect students are very happy in project-based learning, increasing students' interest in learning more actively, and students are not bored in project-based learning. Fourth, in terms of project-based learning tools can be used as self-learning to get an average final score of $74 \%$. For this purpose students are more creative and increase students' interest in independent learning. From the total average value of the four aspects of practical assessment of project-based learning devices on the installation subjects of local network devices of class XI students of Muhammadiyah 1 Padang Vocational School according to the response 29 students were 70\% (Quite Practical).

From these results it is recommended to use project-based learning tools for students. It is hoped that later the other researchers can examine the aspects of students learning independently, because in this study the results are still in the fairly practical category-Quite Practical.

The project-based design aimed at increasing abilities of students' creativity, where students are given direction to be able to express abilities of creativity in learning tools so that students can carry out independent learning. The project-based learning tool was developed in accordance with the material on the subject of local network device installation that was taught to students of class XI in the second semester of TKJ Muhammadiyah 1 Padang Vocational School.

The results of learning materials project-based practicality for the teacher was 85.75\% (Practical) and the student was 70\% (Quite Practical). Project-based learning tools are practical enough to make it easier for students to understand learning installing local network devices with guidance from the teacher.

\section{Conclusion}

This study has provided a reference using a project-based learning model that can be used in learning to install local network devices. This research can provide input to education providers because the media developed can improve student learning outcomes. The teacher can use this learning media so that its use is not only the installation material of local network devices but can be used for other learning.

In the development research using the IDI model it produces a project-based learning device product, practical project-based learning tools on the subject of local net- 
work device installation in the second semester of computer engineering and network class XI at Muhammadiyah I SMK Padang. Project-based learning tools on subjects the installation of local network devices developed is based on competency standards. This project-based learning tool consists of one interrelated basic competency learning that directs students in the initial design of local network devices.

Validation of project-based learning devices after conducting the results of observations or direct observation, curriculum analysis (In-installation syllabus of local network devices), reference book analysis Installation of local network devices and analysis of students. Observation or direct observation aims to pay attention to the characteristics of the learning process, especially unique and comprehensive product learning, the development of learning tools is quite potential to meet the demands of learning. Project-based learning tools can direct students to systematic work procedures and standards for making or completing a product. The curriculum analysis aims to determine the curriculum requirements for the material. While the analysis of students aims to determine the characteristics of students who are used as research subjects. The practicality of project-based learning tools in the learning process is going well. Can be seen student responses to project-based learning devices developed. Where teacher and student answers have been recapitulated into practice tables where the average percentage assessment is $77.87 \%$ which proves that learning devices are based on practical projects by teachers and students. So that the design and impelemtation of project-based learning tools on subject Installing Local Network devices has gone through the practicality test phase. The practicality test results state that this project-based learning tool.

For further research, project-based learning tools on subjects Installing local network devices can be tested on a larger number of trial subjects so that the use of this project-based learning tool would be broader.

\section{Acknowledgement}

This work was supported by Yayasan Amal Bakti Mukmin STMIK Indonesia Padang with contract number: 040/K.A/LPPM/STMIK-I/2019

\section{References}

[1] F. Salam, R. Mailok, N. Ubaidullah, and U. Ahmad, "THE EFFECT OF PROJECTBASED LEARNING AGAINST STUDENTS ' ENGAGEMENT,” Int. J. Dev. Res., vol. 6, no. 2, pp. 6891-6895, 2016.

[2] A. Nasrullah, M. Marlina, and W. Dwiyanti, "Development of Student Worksheet-Based College E-Learning Through Edmodo to Maximize the Results of Learning and Motivation in Economic Mathematics Learning," Int. J. Emerg. Technol. Learn., vol. 13, no. 12, pp. 211-229, 2018. https://doi.org/10.3991/ijet.v13i12.8636

[3] P. Juric, M. B. Bakaric, and M. Matetic, "Design and Implementation of Anonymized Social Network-based Mobile Game System for Learning Mathematics," Int. J. Emerg. Technol. Learn., vol. 13, no. 12, pp. 83-98, 2018. https://doi.org/10.3991/ijet.v13i12.8762 
[4] J. Michael, J. Oshima, and R. Oshima, "Computers \& Education Regulation of collaboration in project-based learning mediated by CSCL scripting re fl ection," Comput. Educ., vol. 125, no. August 2017, pp. 132-145, 2018. https://doi.org/10.1016/j.compedu .2018 .06 .003

[5] S. Aydin, T. D. Atalay, and V. Goksu, "Project-Based Learning Practices with Secondary School Students 1,” Int. Online J. Educ. Sci., vol. 10, no. 3, pp. 230-242, 2018. https://doi. org/10.15345/iojes.2018.03.015

[6] M. Yoshida, "Communication Jigsaw: A teaching method that promotes scholarly communication,” Int. J. Emerg. Technol. Learn., vol. 13, no. 10, pp. 208-224, 2018. https://doi.org/10.3991/ijet.v13i10.8850

[7] D. Tauhidah, H. Susilo, and H. Suwono, "Effect of Project Based Learning Model on the Ability to Read Biology Student Research Articles," J. Educ. Theory, Res. Dev., vol. 3, no. 7, pp. 962-967, 2018.

[8] W. N. Wafula and Ongunya Raphael Odhiambo, "Project Based Learning on Students' Performance in the Concept of Classification of Organisms among Secondary Schools in Kenya," J. Educ. Pract., vol. 7, no. 16, pp. 25-31, 2016.

[9] A. R. Jolanta Lasauskiene, "Project-Based Learning at University: Teaching Experiences of Lecturers," Procedia - Soc. Behav. Sci., vol. 197, pp. 788-792, 2015. https://doi.org/10. $\underline{\text { 1016/j.sbspro.2015.07.182 }}$

[10] C. L. Chiang and H. Lee, "The Effect of Project-Based Learning on Learning Motivation and Problem-Solving Ability of Vocational High School Students," Int. J. Inf. Educ. Technol., vol. 6, no. 9, pp. 709-712, 2016. https://doi.org/10.7763/ijiet.2016.v6.779

[11] H. Roessingh and W. Chambers, "Project-Based Learning and Pedagogy in Teacher Preparation: Staking Out the Theoretical Mid-Ground," Int. J. Teach. Learn. High. Educ., vol. 23, no. 1, pp. 60-71, 2011.

[12] A. Hasani, A. Hendrayana, and A. Senjaya, "Using Project-based Learning in Writing an Educational Article: An Experience Report,” Univers. J. Educ. Res., vol. 5, no. 6, pp. 960964, 2017. https://doi.org/10.13189/ujer.2017.050608

[13] R. M. Gustafson, Kent L.;Branch, Survey Of Instructional Development Models, Third Edit. New York: ERIC Clearinghouse On Information \& Technology, 1997.

[14] I. T. Maulana, "CD Interactive Development for Learning Media on Basic Network Courses,” Indones. J. Comput. Sci., vol. 6, no. 1, pp. 96-108, 2017.

[15] T. U. Dresden, "THE MISSING PRODUCTIVE VOCATIONAL HIGH SCHOOL TEACHER COMPETENCY STANDARD IN THE INDONESIAN,” J. Tech. Educ. Train., vol. 9, no. 1, pp. 26-44, 2017.

[16] F. Firdian and I. T. Maulana, "Development of Interactive Multimedia Learning Media in Software Application Courses,” J. Educ. Theory, Res. Dev., pp. 822-828, 2018. https://doi. org/10.22216/jsi.v3i2.2350

[17] E. Nur, L. Sa, and D. Sigit, "Development of Instruments for Psychomotor Attitudes and Skills Assessment in Electrochemical Materials," J. Educ. Theory, Res. Dev., vol. 3, no. 8, pp. 1023-1026, 2018.

[18] R. Orale, "Senior High School Curriculum in the," J. Acad. Res., vol. 1, no. 3, pp. 12-23, 2017.

[19] A. V Soboleva and A. T. Kerimkulov, "Project Based Learning in Teaching Communication Skills in English as a Foreign Language to Engineering Students," Int. J. Eng. Technol., vol. 11, no. 4, pp. 153-156, 2016. https://doi.org/10.3991/ijet.v11i04.5416

[20] P. Chatwattana and P. Nilsook, "A Web - based Learning System using Project - based Learning and Imagineering," pp. 4-22, 2017. https://doi.org/10.3991/ijet.v12i05.6344 
[21] F. Movahedzadeh, R. Patwell, J. E. Rieker, and T. Gonzalez, "Project-Based Learning to Promote Effective Learning in Biotechnology Courses," Educ. Res. Int. Concept, vol. 2012, pp. 1-8, 2014. https://doi.org/10.1155/2012/536024

[22] M. I. Nasrullah, "TEACHER-STUDENT INTERACTION IN A PROJECT-BASED LEARNING CLASSROOM," J. English Educ., vol. 1, no. 1, pp. 142-153, 2013.

[23] I. Shubina and A. Kulakli, "Pervasive Learning and Technology Usage for Creativity Development in Education Literature Review ( Background of the Study )," Int. J. Emerg. Technol. Learn., vol. 14, no. 1, pp. 95-109, 2019. https://doi.org/10.3991/ijet.v14i01.9067

[24] C. De Simone, J. Lussier, and L. Hall, "Problem-Based Learning in Teacher Education: Trajectories of Change,” Int. J. Humanit. Soc. Sci., vol. 4, no. 12, pp. 17-29, 2014.

[25] Su-ching Lin, "Relationships Among Senior High Vocational School Teacher Teaching Beliefs, Self-Efficacy, Gender, and School Type," J. Soc. Sci. Stud., vol. 2, no. 1, pp. 8797, 2015. https://doi.org/10.5296/jsss.v2i1.6242

[26] Nurwahidah, I. Wilujeng, Jumadi, and Senam, "The Effects of Project Based Learning Model with Android on Scientific Literacy and Digital Equipedness / ICT Literacy," Int. J. Sci. Basic Appl. Res., vol. 36, no. 7, pp. 190-205, 2017. https://doi.org/10.1063/1.4995191

[27] N. Purwanto, Learning Evaluation. Remaja Rosdakarya, 2009.

\section{Authors}

Ilham Tri Maulana is member of the IAENG (International Association of Engineers), Unit 1, 1/F,37-39 Hung to Road, Hong Kong. He works in the Information System Study Program at the Department of Information Systems of STMIK Indonesia Padang, Indonesia. He focused on research in the field of educational technology.

Jufriadi Na'am is Associate Professor in Computer science at Faculty of Computer Science, Universitas Putra Indonesia YPTK Padang, Indonesia. He focused on research in Medical Image Processing, GIS (Geographic Information System), and education learning.

Fadil Firdian is member of the IAENG (International Association of Engineers), Unit 1, 1/F,37-39 Hung to Road, Hong Kong. He works in the Information System Study Program at the Department of Information Systems of STMIK Indonesia Padang, Indonesia. . He focused on research in the field of educational technology and interactive multimedia

Restyaliza Dhini Hary works in Information System Study Program oat the Department of Information Systems of STMIK Indonesia Padang, Indonesia. He focused on research in the field of educational linguistic.

Ratih Purwasih works in Information System Study Program Department of Information Systems of STMIK Indonesia Padang, Indonesia. He focused on research in the field of educational linguistic.

Tri Apriyanto Sundara graduated from Bandung Institute of Tehcnology with a degree in electrical engineering. He currently works as senior lecturer at the Department of Information Systems of STMIK Indonesia Padang, He is a member IEEE and IAENG among others.

Article submitted 2019-02-12. Resubmitted 2019-04-18. Final acceptance 2019-04-19. Final version published as submitted by the authors. 